\title{
LIBERDADE DE IMPRENSA VERSUS PRERROGATIVAS DA ADVOCACIA. ABUSO DE DIREITO NA DIVULGAÇÃO DE NOTÍCIA. CRÍTICA ÁSPERA E OFENSIVA DE JORNALISTA À ATUAÇÃO DO ADVOGADO
}

Romualdo Baptista dos Santos*

\begin{abstract}
Sumário: Introdução - 1. Contornos da garantia constitucional de liberdade de expressão: 1.1. Vertentes e modalidades da liberdade de expressão; 1.2. Liberdade de imprensa e direito à informação; 1.3. Limites e relatividade dos direitos individuais; 1.4. Garantias fundamentais diretamente relacionadas ao estado democrático de direito; 1.5. Disciplina legal da liberdade de imprensa e da liberdade de expressão dos profissionais do direito - 2. O caso Zandonade: 2.1. Síntese do julgado; 2.2. Análise crítica do julgado: questôes periféricas - 3. A questão nuclear decidida no agravo regimental: 3.1 . Sob o prisma das garantias constitucionais: técnica da ponderação; 3.2. Sob a ótica do direito privado: responsabilidade civil por abuso de direito - Conclusão - Referências.
\end{abstract}

\section{INTRODUÇÃO}

O objetivo deste estudo é analisar o eventual conflito entre a liberdade de imprensa e as prerrogativas do advogado, tendo como substrato fático o acórdão prolatado pelo Superior Tribunal de Justiça em ação indenizatória movida pela

Mestre e doutor em Direito Civil pela USP, professor convidado nos cursos de pós-graduação da Escola Paulista de Direito - EPD e da Escola Superior da Procuradoria Geral do Estado de São Paulo - ESPGE, autor e coautor de várias obras e artigos jurídicos. Procurador do Estado de São Paulo. 
procuradora da Fazenda Nacional Adriana Zandonade contra a empresa Folha da Manhã e o jornalista Elio Gaspari.

A questão envolve, antes de tudo, a delimitação dos contornos da garantia constitucional de liberdade de expressão, em suas diversas vertentes: liberdade de imprensa e direito à informação, liberdade artística e literária, expressão da personalidade, liberdade de opinião etc. Da fixação desses contornos resulta a noção de limites ou de relatividade dos direitos individuais, os quais devem se inserir no contexto da convivência em sociedade. De outro lado, as liberdades individuais são tidas como garantias constitucionais, que constituem direitos fundamentais a serem garantidos pelo Estado, mas também configuram direitos da personalidade a serem exercidos no confronto com iguais direitos deferidos às demais pessoas e à sociedade.

No plano do direito privado, o conflito entre as liberdades individuais pode ser tratado pelo prisma da teoria geral da responsabilidade civil, na modalidade dano à pessoa, seja com base na cláusula geral de não lesar seja com base no abuso de direito.

\section{CONTORNOS DA GARANTIA CONSTITUCIONAL DE LIBERDADE DE EXPRESSÃO}

O direito à vida é sem dúvida o mais elementar dos direitos, sem o qual nenhum outro existiria. ${ }^{1}$ Todavia, a vida humana não é mera pulsação do corpo físico, mas sobretudo manifestação e projeção sobre o mundo. Por isso, a pessoa humana é vida que se relaciona, uma vez que só pode ser considerada em suas relações com as demais pessoas e com o ambiente em que vive. ${ }^{2}$

Não sem razão, as principais Cartas de Direitos são uniformes em proclamar a liberdade como corolário de uma existência digna. ${ }^{3}$ Isso significa que, depois do

1 Nesse sentido, confira-se: BITTAR, Carlos Alberto. Os direitos da personalidade. 7. ed. atual. por Eduardo Carlos Bianca Bittar. Rio de Janeiro: Forense Universitária, 2004. p 70-72; FRANÇA, Rubens Limongi. Manual de direito civil. 4. ed. São Paulo: RT, 1980. v. 1, p. 411-412.

2 A noção de que o ser humano é essencialmente relacional é autoevidente, mas pode ser encontrada em diversos autores, como Kaufmann (KAUFMANN, Arthur. La filosofía del derecho en la posmodernidad. 2. ed. Santa Fé de Bogotá: Temis, 1998, p. 67-68), Heidegger (CHAUI, Marilena. Heidegger: vida e obra. São Paulo: Nova Cultural, 1999, p. 9) e Maturana (MATURANA, Humberto. Emoçôes e linguagem na educação e na política. Tradução de José Fernando Campos Fortes. 4. reimp. Belo Horizonte: Editora da UFMG, 2005, p. 92).

3 Declaração dos Direitos do Homem e do Cidadão, de 1789, art. 1º; Declaração Universal dos Direitos Humanos, de 1948, art. $1^{\circ}$. 
direito à vida, a liberdade é provavelmente o mais fundamental dos direitos, sem o qual não seria possível uma vida humana plena de significado. ${ }^{4}$

Em linha com as mencionadas Declarações Universais de Direitos, a Constituição de 1988 estabeleceu a centralidade da pessoa humana em relação ao ordenamento jurídico, em seu art. 1o, III, no Título I, que trata dos Princípios Fundamentais. Em seguida, no Título II, a Constituição apresenta o rol não exaustivo dos Direitos e Garantias Fundamentais, os quais se ligam axiologicamente ao princípio fundamental consignado no Título I. Logo no caput do art. 5ª a Constituição enumera os direitos individuais e coletivos, que serão especificados em seus diversos incisos. O primeiro desses direitos é o direito à vida, que, como se disse acima, é condição de possibilidade de todos os demais. Do ponto de vista do legislador constituinte, a dignidade humana se realiza por meio da preservação desses direitos fundamentais por excelência: vida, liberdade e igualdade. Portanto, vida, liberdade e igualdade constituem um tripé sobre o qual se assenta a dignidade humana.

Ao especificar esses direitos fundamentais ao longo dos incisos do art. $5^{\circ}$, a Constituição se refere à liberdade, em suas mais variadas formas: liberdade de manifestação de pensamento (inciso IV), liberdade religiosa (incisos VI, VII e VIII), liberdade de expressão (inciso IX), liberdade de trabalho, ofício ou profissão (inciso XIII), liberdade de locomoção (inciso XV), liberdade de reunião (inciso XVI) e liberdade de associação (inciso XVII).

Vê-se, portanto, que a liberdade é essencial para que o ser humano se constitua enquanto pessoa. Todavia, considerando que a pessoa é relacional por definição, a liberdade só é possível em um ambiente em que todos tenham igual liberdade de se relacionar e de se projetar sobre o mundo, atribuindo sentido à própria existência. Vale dizer que, se a vida é pulsação, a liberdade é manifestação da existência humana e a igualdade é compreensão da existencialidade do outro. ${ }^{5}$

4 Alexy discorre sobre a ideia de um "direito geral de liberdade" previsto no art. $2^{\circ}, \$ 1^{\mathrm{o}}$, da Constituição alemã, que corresponde ao direito ao livre desenvolvimento da personalidade (ALEXY, Robert. Teoria dos direitos fundamentais. Tradução de Virgílio Afonso da Silva. São Paulo: Malheiros, 1998, p. 341-345). Por seu turno, Rabindranath de Sousa chama a atenção para o aspecto relacional do direito geral de personalidade, à luz do art. $70^{\circ}$ do Código Civil português (SOUZA, Rabindranath Capelo de. O direito geral de personalidade. Lisboa-Coimbra: Coimbra Ed., 2011, p. 515-517).

5 Canotilho escreve que a teoria democrático-funcional dos direitos fundamentais se caracteriza pelo: a) reconhecimento dos direitos fundamentais dos cidadãos, exercidos enquanto membros da comunidade e no interesse público; b) exercício da liberdade como meio de persecução do regime democrático; c) correlação dos direitos aos deveres; d) intervenção restritiva em caso de abuso (CANOTILHO, José Joaquim Gomes. Estudos sobre direitos fundamentais. 1. ed. 3. tir. São Paulo-Coimbra: RT/Coimbra Ed., 2008, p. 34). 


\subsection{Vertentes e modalidades da liberdade de expressão}

Entre os dispositivos constitucionais mencionados, chamam a atenção os incisos IV e IX, que tratam respectivamente da liberdade de expressão em geral e da liberdade de expressão intelectual, artística, científica e de comunicação. Essas disposições constitucionais correspondem àquelas contidas nos arts. $10^{\circ}$ e $11^{\circ}$ da Declaração dos Direitos do Homem e do Cidadão (1789) e nos arts. XVIII e XIX da Declaração Universal dos Direitos humanos (1948), segundo as quais ninguém pode ser molestado por suas opiniões e a livre comunicação de ideias e opiniōes é um dos direitos mais preciosos do homem. ${ }^{6}$

Em seu conjunto, essas disposições constitucionais e convencionais consagram a ideia de liberdade de expressão como gênero que se desdobra em inúmeras espécies, consoante as múltiplas formas de manifestação da personalidade. Considerada a pessoa em sua complexidade, enquanto ente psicofísico e espiritual, em permanente processo de atualização, a liberdade de expressão compreende toda forma de manifestação do corpo, da mente e do espírito da pessoa, limitada unicamente pela igual liberdade conferida às outras pessoas.?

A Constituição disciplina diversas formas de expressão da personalidade, como a manifestação do pensamento, a liberdade intelectual, artística e científica, a liberdade política, a liberdade desportiva, a liberdade religiosa, a liberdade de reunião, a liberdade de trabalho, ofício ou profissão, a liberdade de locomoção, a liberdade de reunião e de associação etc. ( $\mathrm{CF}$, art. $\left.5^{\circ}\right)$, sem prejuízo de outras formas não catalogadas (CF, art. $\left.5^{\circ}, \$ 2^{\circ}\right)$, como é o caso da liberdade de expressão afetiva. ${ }^{8}$

Todos esses direitos constituem expressōes da personalidade que, por conseguinte, ligam-se diretamente ao princípio fundamental da dignidade humana. Além disso, os direitos e garantias individuais dão substância e atribuem sentido à ideia de Estado Democrático de Direito consignada no preâmbulo e no art. $1^{\circ} \mathrm{da}$ Constituição, uma vez que somente em um ambiente de liberdade e igualdade individuais torna-se possível a construção de uma sociedade democrática regida pelo direito, não pela violência, pela tirania e pela força bruta.

6 Declaração dos Direitos do Homem e do Cidadão, 1989, arts. $10^{\circ}$ e $11^{\circ}$. Declaração Universal dos Direitos Humanos, 1948, arts. XVIII e XIX.

7 Ao tratar dos limites da liberdade, Alexy anota, com base no art. 4º, I, da Declaração dos Direitos do Homem e do Cidadão, que não existem outros limites senão aqueles que asseguram igual liberdade a todos os outros membros da sociedade (ALEXY, Robert. Teoria dos direitos fundamentais, cit., p. 371). Em sentido semelhante, confira-se: SOUZA, Rabindranath Capelo de. $O$ direito geral de personalidade, cit., p. 515-517.

8 A esse respeito, confira-se: SANTOS, Romualdo Baptista dos. A tutela jurídica da afetividade. Curitiba: Juruá, 2011, p. 81-86 e 145-147. 
Nesse contexto, alguns dos direitos e garantias individuais adquirem especial relevância para a consolidação e manutenção do processo democrático, como é o caso da liberdade de manifestação de pensamento, crítica e opinião, bem como do direito de reunião e de associação, os quais em regra são suprimidos nos regimes políticos ditatoriais.

\subsection{Liberdade de imprensa e direito à informação}

A liberdade de expressão é condição de possibilidade do Estado Democrático de Direito. Em vista disso, avulta em importância a liberdade de imprensa, que comporta o direito à crítica e à opiniáo inclusive e principalmente sobre a vida política do país. Com efeito, não é possível supor o Estado Democrático de Direito com restrição ou até mesmo supressão da liberdade de pensamento, crítica e opinião sobre os fatos da vida política nacional. Não é por outra razão que os regimes políticos ditatoriais restringem ou suprimem a liberdade de imprensa, via de regra pela estatização dos meios de comunicação, pois sem imprensa livre prevalece a versão dos fatos ditada pelos próprios governantes, com prejuízo para a veracidade.

A liberdade de imprensa está umbilicalmente atrelada ao direito individual à informação, previsto no art. 5, XIV, e nos arts. 220 a 224 da Constituição. Há, como se pode ver, uma conjugação entre a liberdade de informação, que é garantida aos meios de comunicação; e o direito à informação, assegurado a todas as pessoas. Trata-se, portanto, de uma liberdade individual exercida em razão e em prol de outro direito individual. Em conjunto, essas liberdades desempenham uma função indispensável para a manutenção do regime democrático, visto que sem liberdade de informação e sem acesso a informação fidedigna a democracia restaria comprometida. Não sem razão, Luís Roberto Barroso afirma que a livre circulação de ideias é corolário de funcionamento do regime democrático, sobretudo quando veiculada pelos meios de comunicação social ou de massa.

Portanto, a liberdade de informação ou liberdade de imprensa é uma das formas de liberdade de expressão mais relevantes entre os direitos fundamentais, em razão de sua funcionalidade e de sua indispensabilidade para a conservação do processo democrático. Funciona em via de mão dupla entre aquele que desempenha a liberdade de informação e aquele que exerce o direito à informação.

9 BARROSO, Luís Roberto. Colisão entre liberdade de expressão e direitos da personalidade.

Critérios de ponderação. Interpretação constitucionalmente adequada do Código Civil e da

Lei de Imprensa. Migalhas. 


\subsection{Limites e relatividade dos direitos individuais}

No Estado Democrático de Direito, a liberdade se exercita em consonância com a igualdade. Em virtude do princípio da igualdade, todas as liberdades individuais devem ser exercidas em consonância com iguais liberdades conferidas às demais pessoas. ${ }^{10}$ Nesse sentido, Luís Roberto Barroso afirma que não existe hierarquia entre direitos fundamentais, visto que todos ocupam o mesmo patamar jurídico e axiológico, tanto que todos desfrutam da mesma condição de cláusula pétrea constitucional. ${ }^{11}$

Não se pode perder o sentido de que todos os direitos são voltados para a realização da dignidade humana e que as liberdades individuais são essenciais para a preservação do Estado Democrático de Direito. Desse modo, a supremacia de um direito sobre os demais constituiria privilégio inadmissível em benefício de uma classe de pessoas, com prejuízo para as outras. Disso se extrai que, não obstante sua relevância para a estabilidade do regime democrático, a liberdade de imprensa não desfruta de primazia, devendo ser exercida em consonância com as demais garantias e liberdades individuais. ${ }^{12}$

Em vista disso, deve-se afirmar a relatividade dos direitos subjetivos em geral e, em particular, a relatividade dos direitos e garantias individuais, os quais só fazem sentido na medida da realização da dignidade humana e na medida em que forem assegurados a todas as pessoas em pé de igualdade.

\subsection{Garantias fundamentais diretamente relacionadas ao Estado Democrático de Direito}

Todos os direitos e garantias individuais são relacionados ao princípio da dignidade da pessoa humana, o qual constitui o norte axiológico e epistemológico de

$10 \mathrm{O}$ art. $1^{\circ}$ da Declaração dos Direitos do Homem e do Cidadão, de 1789, diz que os homens nascem livres e iguais; e o art. $4^{\circ} \mathrm{diz}$ que a liberdade consiste em poder fazer tudo que não prejudique o próximo, de modo que os direitos de cada homem têm como limite o gozo de iguais direitos pelos demais membros da sociedade. Também a Declaração Universal dos Direitos Humanos, de 1948, diz que os seres humanos são livres e iguais em dignidade e direitos e que todos têm capacidade para gozar dos direitos e liberdades estabelecidos na Declaração (arts. I e II).

11 BARROSO, Luís Roberto. Colisão entre liberdade de expressão e direitos da personalidade, cit.

12 Nesse sentido, o enunciado 613 da VIII Jornada de Direito Civil, realizada em 2018 pelo Conselho da Justiça Federal: Enunciado 613 - Art. 12: A liberdade de expressão não goza de posição preferencial em relação aos direitos da personalidade no ordenamento jurídico brasileiro. 
todo o sistema jurídico..$^{13}$ Ademais, a preservação da pessoa e de sua dignidade, pela via das liberdades democráticas, constitui fator de instauração e preservação do Estado Democrático de Direito. No entanto, algumas garantias estão umbilicalmente relacionadas à preservação do regime democrático, como é o caso da liberdade de informação e de imprensa, sem a qual não seria possível o Estado Democrático de Direito.

A liberdade de pensamento, crítica e opinião pode se dar no plano individual, uma vez que a Constituição assegura a cada pessoa o gozo de sua liberdade de expressão em gênero, que compreende o direito de manifestar suas ideias, pensamentos, críticas e opiniões sobre qualquer fato da vida. Todavia, essa liberdade individual é alimentada por informações que circulam de forma organizada pelos meios de comunicação social, sem as quais o direito individual de se manifestar restaria seriamente comprometido. Percebe-se, portanto, que o fluxo de informações alimenta a liberdade de expressão, de sorte que a supressão do primeiro inviabiliza a segunda.

Não se deve olvidar que o fluxo de informações contém diversas distorções de sentido e de conteúdo, mas somente o exercício da liberdade de expressão torna o indivíduo capaz de discernir entre o falso e o verdadeiro, o reto e o distorcido, formando sua própria opinião crítica. Portanto, não se pode, a pretexto de coibir informaçôes falsas e distorcidas, suprimir ou restringir a liberdade de expressão e, em especial, a liberdade de imprensa, sob pena de inviabilizar o direito à informação e comprometer o regime democrático.

Todavia, a preservação do Estado Democrático de Direito não se exaure com o exercício da liberdade de informaçãa. Há outros fatores que são igualmente indispensáveis para a preservação do regime democrático, como é o caso das prerrogativas da magistratura e da advocacia, que também são aspectos da liberdade de expressão, porém relacionados ao adequado funcionamento do sistema de justiça. Bem por isso, a Constituição e as leis orgânicas garantem prerrogativas funcionais aos membros das carreiras jurídicas, como juízes, promotores, procuradores, defensores públicos e advogados, com especial ênfase à liberdade de expressão de pensamento no âmbito dos processos judiciais e administrativos.

13 FACHIN, Luiz Edson. Teoria crítica do direito civil. 2. ed. Rio de Janeiro: Renovar, 2003, p. 18 e 218; FACHIN, Luiz Edson. Estatuto jurídico do patrimônio minimo. 2. ed. Rio de Janeiro: Renovar, 2006, p. 48. BARROSO, Luís Roberto. Neoconstitucionalismo e constitucionalização do direito (o triunfo tardio do direito constitucional no Brasil). Revista de Direito Administrativo, Rio de Janeiro: FGV, p. 1-42, abr.-jun. 2005. Disponível em: <http://bibliotecadigital.fgv. br/ojs/index.php/rda/article/view/43618/44695>. Acesso em: 29 maio 2018. 
Essas prerrogativas são garantias individuais, mas também garantias funcionais e institucionais a serem exercidas no desempenho de profissões relacionadas ao sistema de justiça. São formas de liberdade de expressão asseguradas a seus titulares, mas em benefício da coletividade, para o adequado funcionamento do sistema de justiça. Com efeito, não se pode admitir a supressão da liberdade de expressão do juiz ao proferir uma decisão judicial, assim como dos advogados, promotores e defensores ao realizarem suas petições e arrazoados, sob pena de comprometer o adequado funcionamento do sistema de justiça.

Entre nós, o exemplo mais eloquente de castração das liberdades democráticas se deu com a promulgação dos Atos Institucionais, que representaram o recrudescimento do Regime Militar. O art. 14 do AI-2 e o art. $6^{\circ}$ do AI-5 suspenderam expressamente as garantias de magistratura e atribuíram ao Presidente da República poderes para demitir, remover, aposentar ou colocar magistrados em disponibilidade. O art. 10 do AI-5 suprimiu a garantia do habeas corpus e o art. 11 vedou a apreciação judicial de atos praticados pelo Regime. Com isso, a restrição à liberdade de expressão imposta às pessoas em geral foi estendida aos membros da magistratura, que não podiam deliberar livremente sobre as questôes que lhes fossem submetidas.

No que se refere especificamente aos advogados, a liberdade de expressão é garantia que possibilita a postulação de direitos individuais junto ao Poder Judiciário e às instâncias administrativas do poder público. Por isso, o legislador constituinte ressalta esse aspecto, diretamente no texto constitucional, ao dizer que o advogado é indispensável à administração da justiça e inviolável por seus atos e manifestações (CF, art. 133).

Em períodos de exceção política e institucional, a liberdade dos advogados em regra é restringida por meio de leis e decretos que impedem a postulação de certos direitos. $\mathrm{O}$ comprometimento da liberdade de expressão do advogado pode se dar por vários modos, como a subordinação às demais carreiras jurídicas, a intimidação, o aviltamento de seus honorários e, sobretudo, por meio da restrição ao uso da palavra verbal ou escrita.

Ocorre que a atividade advocatícia consiste em postular os direitos de seus clientes junto ao poder público, de modo que a restrição à liberdade de expressão do advogado atinge sua própria dignidade profissional, mas acima de tudo atinge os direitos e interesses de terceiros que estão sob seus cuidados. Por isso, no sistema jurídico atual, deve ser prestigiada a liberdade de expressão do advogado, ressalvado apenas o uso de expressões injuriosas (CF, art. 133; EOAB, art. $7^{\circ}, \mathrm{XX}, \S 2^{\circ}$; CPC, art. 78). 
Assim como a liberdade de imprensa e o direito à informação são essenciais para a preservação das liberdades democráticas, também a liberdade de expressão dos profissionais do direito é indispensável para o perfeito funcionamento do Estado Democrático de Direito. Tanto isso é fato que tanto a liberdade de imprensa quanto a liberdade de expressão dos profissionais da justiça só florescem e vicejam nos regimes políticos minimamente democráticos. Os regimes totalitários são incompatíveis com a liberdade de expressão em geral e, em particular, com a liberdade de informação e a independência dos profissionais do direito.

\subsection{Disciplina legal da liberdade de imprensa e da liberdade de expressão dos profissionais do direito}

A liberdade de expressão é gênero do qual são espécies as inúmeras formas de manifestação do corpo, da mente e do espírito da pessoa humana. Entre as várias formas de liberdade de expressão, destaca-se a liberdade de informação ou de imprensa, que desempenha papel fundamental para o exercício das liberdades políticas e democráticas. Outra forma de liberdade de expressão igualmente importante para a preservação do Estado Democrático de Direito é a liberdade de manifestação dos juízes, advogados, promotores, procuradores e defensores no exercício das atividades profissionais voltadas para a realização da justiça.

A liberdade de expressão como gênero encontra-se inscrita no art. $5^{\circ}$, IV e IX, da Constituição, observando-se que o próprio texto constitucional relativiza o exercício dessas liberdades nos incisos $\mathrm{V}$ e X. Lidos em conjunto, pode-se compreender que é livre a manifestação de pensamento, mas é assegurado o direito de resposta e a reparação por dano moral e material (incisos IV e V). Ou, ainda, é livre a expressão intelectual, artística e científica, observado o respeito à intimidade, à privacidade, à honra e à imagem das outras pessoas (incisos IX e X).

A liberdade de imprensa é forma de liberdade de expressão organizada pelos meios de comunicação social que se coordena com o direito individual à informação $(\mathrm{CF}$, art. 50, XIV). É um direito dúplice que se realiza em uma relação dialógica entre aquele que exercita uma liberdade e aquele que desfruta de um direito. Por sua relevância para o funcionamento e preservação do regime democrático, a Constituição disciplina esse direito no capítulo Da Comunicação Social, enfatizando a vedação a toda forma de censura (CF, art. 220).

No plano infraconstitucional, há uma tradição pela preservação da liberdade de imprensa, temperada com o respeito aos direitos da personalidade das outras pessoas. Assim, a Lei 2.083, de 12 de novembro de 1953, editada sob o segundo 
governo de Getúlio Vargas, estabelecia que é livre a publicação e a circulação de jornais e outros periódicos em todo o território nacional (art. 10), mas previa a imposição de multas e sançôes criminais aos que cometessem abuso (art. $8^{\circ}$ e seguintes), bem como obrigava ao direito de resposta a quem se sentisse ofendido (art. 17 e seguintes). Em pleno auge da ditadura militar, foi editada a Lei 5.250, de 9 de fevereiro de 1967, cujo art. $1^{\circ}$ dispunha que é livre a manifestação de pensamento e a difusão de informações e ideias, independentemente de qualquer censura e resguardado o sigilo das fontes, com previsão do direito de resposta e de sanções pecuniárias e criminais aos que cometessem abuso.

Ocorre que o Supremo Tribunal Federal declarou, por maioria de votos, a inconstitucionalidade da Lei 5.250/67, ao julgar a Arguição de Descumprimento de Preceito Fundamental 130, em 30 de abril de 2009, uma vez que a lei é incompatível com os princípios que norteiam a Constituição de $1988 .{ }^{14}$ Diante da inconstitucionalidade da Lei 5.250/67, a matéria restou disciplinada diretamente pelos arts. 220 a 224 da Constituição, aplicando-se a legislação infraconstitucional comum sobre a responsabilidade civil e criminal por atos cometidos em razão do exercício da liberdade de informação. De edição recente, a Lei 13.188, de 11 de novembro de 2015, disciplina o direito de resposta, de retratação e de retificação de dados em matéria jornalística, sem prejuízo da responsabilidade civil e criminal, na esteira do que se encontra previsto no art. $5^{\circ}$, V, da Constituição.

De igual modo, a liberdade de manifestação dos magistrados e dos advogados em geral constitui espécie do gênero liberdade de expressão. No quadro geral dos direitos e garantias individuais, trata-se de liberdade intelectual, científica e profissional (incisos IX e XIII). No plano mais específico, a Constituição trata das prerrogativas dos magistrados no art. 95 e consagra todo o Capítulo IV às Funçōes Essenciais à Justiça: Ministério Público (arts. 127 e seguintes), Advocacia Pública (arts. 131 e 132), Advocacia em geral (art. 133) e Defensoria Pública (arts. 134 e 135).

No que diz respeito especificamente aos advogados, a Constituição é expressa ao consignar sua indispensabilidade à administração da justiça e sua inviolabilidade por atos e manifestações no exercício da profissão (art. 133). Ademais, todas as carreiras jurídicas são regidas por estatutos próprios, que especificam as prerrogativas de seus membros. No caso dos advogados, o Estatuto foi positivado pela Lei 8.906, de 4 de julho de 1994, cujo art. $2^{\circ}$ repete as disposições constitucionais de

14 Disponível em: <http://www.stf.jus.br/portal/cms/vernoticiadetalhe.asp?idconteudo=107402>. Acesso em: 9 jul. 2018. 
que o advogado é indispensável à administração da justiça e inviolável por seus atos e manifestações no exercício da profissão.

Aos dispor sobre as prerrogativas do advogado, o art. $7^{\circ}$ do Estatuto destaca a liberdade no exercício da profissão, a inviolabilidade de seu escritório (incisos I e II). Todavia, em todas as prerrogativas do advogado está presente a liberdade de se expressar e de se manifestar, verbalmente ou por escrito, postular, reclamar, permanecer e se retirar, dirigir-se aos magistrados (inciso VIII), usar a palavra, falar sentado ou em pé. Ou seja, a liberdade de expressão e de manifestação de pensamento é indissociável da atividade profissional do advogado.

Considerando que a atividade do advogado se confunde com a capacidade de argumentar em defesa dos interesses de seu cliente, não se pode conceber restrição a sua liberdade de expressão no âmbito do Estado Democrático de Direito. Ou seja, o profissional do direito existe para argumentar em favor de seu cliente, seja ele um particular, seja o Estado, no caso dos advogados públicos, seja o interesse público, no caso do Ministério Público, seja ainda a causa dos necessitados, quando se trata da Defensoria Pública. Eventual restrição à liberdade de expressão no exercício dessas profissões significaria inadmissível amputação ao Estado Democrático de Direito.

\section{O CASO ZANDONADE}

$\mathrm{O}$ caso Zandonade bem exemplifica o eventual atrito entre liberdade de imprensa e as prerrogativas da advocacia. A procuradora da Fazenda Nacional Adriana Zandonade moveu ação de indenização por danos morais contra o jornalista Elio Gaspari e a empresa jornalística Folha da Manhã, em razão de críticas lançadas em matéria jornalística publicada no jornal Folha de S. Paulo de 12 de março de 2000, da qual se extraem os seguintes trechos: $:^{15}$

O médico do DOI deixou uma aula para a procuradora Zandonade.

A procuradora da Fazenda Nacional Adriana Zandonade quer inaugurar um novo capítulo na história dos direitos humanos no Brasil.

(...)

Atualmente, Inês Etienne Romeu está na Justiça, pedindo que se reconheça que foi mantida em cárcere privado por torturadores a serviço do governo da época. Não quer mais nada. Não está pedindo indenização pelo que lhe fizeram.

A doutora Zandonade sustentou que a denúncia de tortura e cárcere privado não se sustenta porque Inês "nem sequer identifica" as pessoas que a mantiveram em cativeiro.

15 O texto integral está disponível em <http://www1.folha.uol.com.br/fsp/brasil/fc1203200012. htmm>. Acesso em: 10 maio 2018. 
-. Direito Civil: Estudos | Coletânea do XV Encontro dos Grupos de Pesquisa - IBDCivil

Foi clara: "caberia à requerente indicar com clareza quem é o autor dos atos de tortura, incumbindo-lhe produzir a prova".

Beleza. Nesse caso, não desapareceu ninguém na guerrilha do Araguaia. Primeiro, porque o Exército jamais admitiu a sua existência. Segundo, porque os desaparecidos desapareceram. Da mesma forma, ninguém pode dizer que foi torturado no DOI-Codi, a menos que traga a identidade do torturador e o livro de ponto do calabouço. Os procuradores são pagos para defender os interesses do Estado, mas qualquer vestibulando de direito sabe que isso não significa defender crimes praticados pelos governantes.

(...)

Uma coisa é certa. A doutora Zandonade conseguiu entrar para a pobre história dos direitos humanos nacionais. Não há por que duvidar de que ostentará a sua contestação ao caso de Inês Etienne como um indicador de sua competência profissional.

A ação foi julgada parcialmente procedente em primeiro grau, condenados os réus a pagar o equivalente a 200 salários mínimos à autora a título de reparação moral. O Tribunal de Justiça do Estado de São Paulo manteve a procedência parcial da ação, mas reduziu o montante indenizatório para o equivalente a 70 salários mínimos. Eis a ementa do julgado:

RESPONSABILIDADE CIVIL. DIREITO À INFORMAÇÃO. LIBERDADE DE IMPRENSA. NOTÍCIA VEICULADA EM JORNAL DE GRANDE CIRCULAÇÃO. SOBEJA O DIREITO DE NARRAR. ASSERÇÕES DESPROPOSITADAS. VIOLAÇÃO DE DIREITO DA PERSONALIDADE. HONRA OFENDIDA. DANO MORAL CARACTERIZADO. VERBA HONORÁRIA MANTIDA. "QUANTUM" INDENIZATÓRIO DESMEDIDO. RECURSO PARCIALMENTE PROVIDO.

Diante desse resultado, as partes movimentaram Recursos Especiais, aos quais foi negado seguimento, desafiando agravos de instrumento ao Superior Tribunal de Justiça. O acórdão discutido no presente estudo foi proferido no Agravo Regimental 127.467-SP contra decisão que havia rejeitado os Agravos de Instrumento em Recurso Especial interpostos pelas partes. O Superior Tribunal de Justiça acolheu o Agravo Regimental para conhecer e dar provimento ao Recurso Especial, a fim de julgar improcedente a ação indenizatória.

\subsection{Síntese do julgado}

No Superior Tribunal de Justiça, os Agravos de Instrumento em Recurso Especial foram distribuídos ao Ministro Marco Buzzi, da Quarta Turma, que negou seguimento ao Recurso Especial por entender que o acórdão do Tribunal de Justiça enfrentou todos os aspectos da causa e que a análise do recurso demandaria incursão sobre a matéria fática, o que é vedado pela Súmula 7 do STJ. 
Essa posição do Ministro Relator foi sustentada quando da apreciação do Agravo Regimental em Agravo de Instrumento em Recurso Especial 127.467-SP, conforme se lê em seu voto vencido. Porém, o Ministro Luís Felipe Salomão pediu vista e instaurou a divergência, no que foi seguido pelos Ministros Antônio Carlos Ferreira e Raul Araújo. A Ministra Maria Isabel Gallotti, presidente da Turma, votou com o relator. Para maior clareza, confira-se a ementa do julgado:

EMENTA

AGRAVO REGIMENTAL NO AGRAVO EM RECURSO ESPECIAL. RESPONSABILIDADE CIVIL. NOTÍCIA VEICULADA EM JORNAL DE GRANDE CIRCULAÇÃO. CRÍTICA FORMULADA CONTRA SERVIDORA PÚBLICA. ATUAÇÃO DE PROCURADORA EM DEMANDA JUDICIAL. INEXISTÊNCIA DE OFENSA A DIREITO DA PERSONALIDADE. VALORAÇÃO PROBATÓRIA. POSSIBILIDADE. QUESTÃO BEM DELINEADA NO ACÓRDÃO RECORRIDO. RECURSOS DA PARTES RÉS PROVIDOS. PEDIDO JULGADO IMPROCEDENTE. PREJUDICADO O APELO DA PARTE AUTORA.

1. A análise da controvérsia prescinde de reapreciação do conjunto fático-probatório, bastando a valoração de fatos perfeitamente admitidos pelas partes e pelo órgão julgador, atribuindo-lhes o correto valor jurídico. Na hipótese, a questão controvertida está bem delineada no acórdão recorrido, razão pela qual não há incidência do enunciado da Súmula 7/STJ.

2. As pessoas consideradas públicas estão sujeitas a maior exposição e suscetíveis a avaliações da sociedade e da mídia, especialmente os gestores públicos de todas as esferas de poder, mesmo quando envolvidos em processos judiciais - que, em regra, não correm em segredo de justiça - como partes, procuradores ou juízes.

3. No caso dos autos, o jornalista apresentou sua opinião crítica acerca dos argumentos utilizados pela Procuradora da Fazenda Nacional na contestação apresentada pela União em autos de ação declaratória movida por Inês Etienne Romeu, sem, contudo, atingir a honra e a imagem da autora.

4. A ponderação trazida pelo articulista procura rechaçar a tese alegada pela União de se exigir a identificação dos responsáveis pela prática de tortura dentro da chamada "Casa da Morte". Para isso, faz uma análise crítica da atuação da procuradora, mas sem transbordar os limites da garantia de liberdade de imprensa, a ponto de configurar abuso de direito.

5. Agravo regimental provido, para conhecer do agravo e dar provimento aos recursos especiais interpostos por Empresa Folha da Manhã S.A. e Elio Gaspari, para julgar improcedentes os pedidos iniciais. Prejudicado o apelo apresentado pela parte autora.

\subsection{Análise crítica do julgado: questões periféricas}

Os Recursos Especiais se baseavam em três argumentos: a) negativa de jurisdição pela Corte estadual; b) ausência de ato ilícito a fundamentar o dever de 
indenizar; c) termo inicial para incidência dos juros de mora. Ao negar seguimento aos Recursos Especiais, a Corte estadual argumentou que (d) o conhecimento dos recursos demandaria incursão sobre a matéria fática, argumento este encampado pelo Ministro Relator Marco Buzzi ao negar provimento aos Agravos de Instrumento em Recurso Especial por decisão monocrática.

Conforme se pode observar, há uma questão nuclear, que é a ocorrência de ato ilícito e, por conseguinte, a existência do dever de indenizar; e três questões periféricas, que dizem respeito a aspectos processuais e ao termo inicial da contagem dos juros de mora.

A alegação de negativa de jurisdição é recorrente no meio forense e se refere à necessidade de se enfrentar, nas sentenças e nos acórdãos, todos os argumentos suscitados pelas partes. O problema não é recente e até foi objeto de disposição expressa no novo Código de Processo Civil: não se considera fundamentada qualquer decisão judicial que não enfrenta todos os argumentos capazes de infirmar a conclusão adotada pelo julgador ou que se limita a invocar precedente ou súmula (CPC, art. 489, $\$ 1^{\circ}, \mathrm{IV} \mathrm{e} \mathrm{V)}$. A matéria inclusive encontra assento constitucional, já que o art. 93, XI, da Constituição impõe que todas as decisões sejam fundamentadas.

Porém, há entendimento assentado na jurisprudência no sentido de que o juiz não está obrigado a responder a todos os questionamentos formulados pelas partes, mas somente àqueles que entender pertinentes ao deslinde da causa (STF, Pleno, Rcl 2.990-AgR-ED, Rel. Min. Menezes Direito, Tribunal Pleno, DJe 07.12.2007; RE 465.739-AgR-ED, Rel. Min. Ayres Britto, Primeira Turma, DJ 24.11.2006; AI 417.161-AgR, Rel. Min. Carlos Velloso, Segunda Turma, DJ 21.03.2003).

Trata-se de uma questão que está longe de ser pacificada porque a avaliação sobre a imprescindibilidade de determinado argumento incumbe ao juiz. $\mathrm{Na}$ maior parte dos casos, a parte entende que determinado argumento poderia modificar o resultado do julgamento, trazendo-lhe resultado favorável. No entanto, o juiz pode se valer de outros argumentos e, eventualmente, encontrar solução diversa daquela pretendida pela parte. Nesse caso, não se pode falar em negativa de jurisdição porque, embora o juiz tenha passado ao largo de determinado argumento da parte, sua decisão encontra-se apoiada em outros argumentos capazes de lhe dar sustentação.

No caso em comento, o Superior Tribunal de Justiça afastou, à unanimidade, a alegação de negativa de jurisdição porque a Corte estadual enfrentou suficientemente os argumentos trazidos pelas partes, citando farta jurisprudência da própria Corte Superior. Sem grande esforço, pode-se perceber que a questão se refere à valoração de fato incontroverso nos autos, a saber se a notícia veiculada pelos réus configuraria ofensa aos direitos da personalidade da autora. 
Sobre a contagem dos juros de mora, trata-se de questão tormentosa porque a redação da súmula 54 do Superior Tribunal de Justiça é extremamente abrangente, ao dizer que os juros de mora fluem a partir do evento danoso em caso de responsabilidade extracontratual. No entanto, em se tratando de danos morais, o valor da condenação só é conhecido quando de seu arbitramento pelo juiz ou tribunal. Diante disso, o próprio Superior Tribunal de Justiça tem reconhecido que não se pode falar de mora antes de ser conhecido o valor do débito (STJ, Recurso Especial 903.258/RS, Rel. Min. Maria Isabel Gallotti, j. 21.06.2011, maioria). Em sentido semelhante, o Tribunal Superior do Trabalho assentou o entendimento de que os juros correm a partir da citação (TST, súmula 439). ${ }^{16}$

No caso em comento, essa questão não chegou a ser enfrentada pelo Superior Tribunal de Justiça, primeiro porque foi negado seguimento aos Recursos Especiais, depois porque o julgamento teve como resultado a improcedência da ação, restando prejudicada a questão dos juros de mora.

Por fim, ainda no que diz respeito às questôes periféricas, o Superior Tribunal de Justiça afastou o óbice da súmula 7, segundo a qual o Recurso Especial não se presta à reapreciação da prova. $\mathrm{O}$ argumento foi utilizado pelo Tribunal de origem para negar seguimento aos Recursos Especiais e encampado pelo Ministro Relator para negar provimento aos Agravos em Recurso Especial, por decisão monocrática.

Observa-se que o Tribunal de origem incorreu em equívoco recorrente nessa parte ao entender que a súmula 7 impede a apreciação dos fatos da causa, quando a rigor a súmula impede somente a reapreciação das provas. Com efeito, a regra constante do art. 105, III, $a$, da Constituição diz que cabe recurso especial para corrigir contrariedade ou negativa de vigência à lei federal, o que conduz à ideia de que só cabe recurso especial para apreciar matéria de direito. No entanto, a aplicação do direito não pode incidir sobre o nada existencial, mas é necessário constatar a existência de um fato sobre o qual deve recair a regra jurídica.

Portanto, a teor da súmula 7 do Superior Tribunal de Justiça, o recurso especial incide sobre os fatos da causa, os quais, no entanto, devem estar comprovados. Por conseguinte, não se admite recurso especial para discutir a incidência da lei federal sobre fatos que não estão suficientemente comprovados. Neste ponto, a divergência inaugurada pelo Ministro Luís Felipe Salomão é de grande acerto e

16 Com base nessas considerações, este autor publicou recente estudo sobre o termo inicial da contagem de juros de mora, em caso de condenação por danos morais (SANTOS, Romualdo Baptista dos. Pela atualização da súmula 54 do STJ. Revista de Estudos Jurídicos e Sociais, 6. ed., n. 6, p. 57-77, out. 2017. Também disponível em formato digital, no endereço: <http://www. univel.br/ojs/index.php/revista/article/view/11>). 
precisão, porque a notícia veiculada pelos réus é fato incontroverso nos autos. Mais do que isso, é fato público e notório, tanto que foi veiculado em jornal de grande circulação.

\section{A QUESTÃO NUCLEAR DECIDIDA NO AGRAVO REGIMENTAL}

A questão central enfrentada no Agravo Regimental no Agravo em Recurso Especial 127.467-SP é se a publicação da notícia intitulada "O médico do DOI deixou uma aula para a procuradora Zandonade", veiculada no jornal Folha de S. Paulo de 12 de março de 2000, constitui ofensa aos direitos da personalidade da procuradora da Fazenda Nacional, a ponto de ensejar indenização por danos morais.

\subsection{Sob o prisma das garantias constitucionais: técnica da ponderação}

Ao acolher os Recursos Especiais do jornalista e da empresa jornalística, o Superior Tribunal de Justiça recorreu à técnica da ponderação dos direitos fundamentais, cuja base doutrinária encontra-se em Alexy, mas não lançou mão de seu método para solucionar o caso. Segundo Luís Roberto Barroso, a ponderação consiste em uma técnica de decisão jurídica aplicável a casos difíceis, nos quais a subsunção se mostra insuficiente, dada a existência de normas de mesma hierarquia que indicam soluções diferenciadas. Sua aplicação se dá em três passos: primeiro, deve o intérprete identificar as normas aplicáveis ao caso e que se acham em conflito; em seguida, deve analisar os fatos e sua interação com os elementos normativos; de posse desses fatores, deve sopesar e decidir qual grupo de normas deve prevalecer sobre o outro com o qual se acha em conflito, tendo como fio condutor a proporcionalidade e a razoabilidade. ${ }^{17}$

A rigor, o julgador apenas mencionou a técnica da ponderação, sem aplicá-la efetivamente. Limitou-se a realizar apreciação pessoal, subjetiva, em que minimiza a agressividade das expressóes contidas na reportagem e assevera que as pessoas que desempenham funções públicas estão sujeitas a esse tipo de avaliação (item 3.4 do acórdão).

De todo modo, o caso não comportaria a aplicação da técnica de ponderação, uma vez que não se trata de hard case que não possa ser solucionado pela técnica da subsunção. Ademais, não se trata de decidir conflito entre os conjuntos normativos

17 BARROSO, Luís Roberto. Colisão entre liberdade de expressão e direitos da personalidade. cit. Confira-se também ALEXY, Robert. Teoria dos direitos fundamentais, cit., p. 91-103. 
que regem as atividades do jornalista e da advogada. Conforme assinalamos na primeira parte deste estudo, tanto a liberdade de imprensa quanto as prerrogativas da advocacia ocupam patamar hierárquico e axiológico equivalente, pois convergem igualmente para a realização da dignidade humana e para a conservação do Estado Democrático de Direito.

Portanto, a questão posta em juízo não comportava a aplicação da técnica da ponderação, mas deveria se resolver pelas regras do direito privado, mediante análise das condutas comprovadas nos autos e sua subsunção às regras da responsabilidade civil, a fim de apurar em que medida a conduta do jornalista ultrapassou os limites de sua liberdade e atingiu a dignidade pessoal e profissional da advogada.

\subsection{Sob a ótica do direito privado: responsabilidade civil por abuso de direito}

Considerando os mais recentes desenvolvimentos da teoria da responsabilidade civil, que põem em proeminência o direito da vítima à reparação do dano, deve-se perquirir inicialmente se a procuradora da Fazenda Nacional sofreu abalo em sua dignidade moral e profissional em decorrência da matéria jornalística.

Extrai-se da simples leitura da reportagem que a conduta do jornalista ultrapassou em muito os limites de seu dever de informar, opinar e criticar, colocando em dúvida a competência profissional da procuradora e acusando-a de defensora dos torturadores da Ditadura Militar. O jornalista se prevalece de sua condição para atacar a dignidade pessoal e profissional da advogada que, conforme se disse, também desfruta de liberdade de expressão. Nesse sentido, tanto a sentença de primeiro grau quanto o acórdão que a confirmou em segundo grau são firmes em afirmar que a procuradora sofreu "profundo abalo psíquico, perturbação de sua tranquilidade e desdouramento de sua imagem enquanto pessoa estudiosa e competente" (item 6 do acórdão do TJSP).

Urge destacar que a procuradora da Fazenda Nacional limitou-se a suscitar tese em defesa do interesse da União, no sentido de que o pedido da autora em ação declaratória depende da comprovação do fato alegado cuja declaração se pretende. Essa tese, por sinal, não é destituída de sentido, visto que encontra guarida na legislação processual (CPC/1973, art. 333, I; CPC/2015, art. 373, I). Não se pode perder de vista que, nesses casos, a ação declaratória tem por finalidade última a obtenção de algum benefício pecuniário ou indenização, como se fosse uma ação indenizatória em dois estágios. Atenta a essa potencialidade da ação declaratória, a procuradora da Fazenda Nacional apontou desde logo a fragilidade dos elementos de convicção acerca do fato alegado. 
É evidente que, no âmbito da dialética processual, o juiz da causa poderia dispensar a autora da comprovação exigida pela procuradora, uma vez que a própria lei contém exceções à regra sobre ônus da prova, bem como se valer de outros elementos de convicção, como documentos e testemunhos, para concluir que a parte realmente foi presa e torturada. Essa circunstância, porém, não retira da advogada o direito de suscitar argumento que possa favorecer a posição jurídica de seu cliente, no caso a União. Vale dizer que a procuradora tem o direito e o dever funcional de apontar eventual insuficiência dos elementos de convicção fornecidos pela parte autora da ação declaratória, mesmo que ao final seu argumento seja rejeitado pelo juiz.

É indispensável ressaltar que, a esta altura de nosso processo histórico, ninguém em sã consciência seria capaz de levantar a voz em defesa dos crimes cometidos durante a Ditadura Militar. No caso, portanto, não se trata de defender torturadores, como maldosamente assinalado na reportagem jornalística, mas de defender o Estado em ação declaratória para a qual se exige comprovação do fato a ser declarado.

$\mathrm{Na}$ reportagem veiculada na Folha de S. Paulo, o jornalista distorce propositalmente o sentido da notícia, ao afirmar textualmente, em tom jocoso e depreciativo, que a procuradora defende torturadores e que é destituída de competência profissional. É indiscutível que o jornalista tem direito de exercitar a liberdade de imprensa, veiculando notícias, informações, críticas e opiniōes, cujas consequências as pessoas estão obrigadas a suportar, em virtude da própria Constituição. Porém, a partir do momento em que se afasta de seu dever de informar, opinar e criticar e ingressa no terreno das ofensas gratuitas que não contribuem para a elucidação dos fatos, o jornalista se desvia da finalidade social de seu mister e pratica abuso de direito, que é ato ilícito e enseja o dever de indenizar.

O tratamento dos danos sofridos pela advogada em razão dos excessos cometidos pelo jornalista pode ser realizado pela ótica do abuso de direito, uma vez que o art. 187 do Código Civil diz que também pratica ato ilícito aquele que se excede no exercício de um direito. É intenso o debate doutrinário sobre a estrutura e a natureza jurídica do abuso de direito, em que o agente pode ser responsabilizado mesmo agindo dentro do seu direito. ${ }^{18}$ Nas palavras de Silvio Rodrigues, ocorre abuso de direito quando o agente atua dentro das prerrogativas que o ordenamento lhe concede, mas se afasta da finalidade social do direito subjetivo, causando dano a outrem. ${ }^{19}$ Em igual sentido, Alvino Lima sustenta que comete abuso de direito aquele que age nos estritos limites da lei, mas viola os princípios de sua finalidade

18 GONÇALVES, Carlos Roberto. Responsabilidade civil. 9. ed. São Paulo: Saraiva, 2005, p. 57-58.

19 RODRIGUES, Silvio. Direito civil: v. 4 - responsabilidade civil. 4. ed. São Paulo: Saraiva, 1979, p. 49. 
econômica e social, produzindo desequilíbrio entre o interesse individual e o coletivo. ${ }^{20}$ Entre os doutrinadores contemporâneos, Flávio Tartuce aprecia o instituto pelo prisma da função social dos negócios jurídicos, ao dizer que comete abuso de direito quem se afasta dos princípios da socialidade e da eticidade. ${ }^{21}$

Percebe-se, no entanto, que o abuso de direito dialoga com o exercício regular de um direito para fim de caracterização da ilicitude. Até o ponto em que o agente atua no exercício regular de seu direito não há ilicitude porque a outra pessoa está obrigada a suportar as consequências daquele ato, em virtude da lei ou do contrato. ${ }^{22}$ Nesse caso, não se pode sequer falar propriamente em dano, mas em mero prejuízo, posto que destituído de ilicitude. A partir do momento em que o titular se excede no exercício de seu direito, verifica-se o abuso, que é ilícito e contamina o prejuízo com sua ilicitude, transformando-o em dano que a vítima não está obrigada a suportar. ${ }^{23}$

Logo, o abuso de direito constitui categoria autônoma de ilícito, que se diferencia do ilícito puro, pois a conduta é lícita no exercício regular do direito, mas ilícita no exercício abusivo. ${ }^{24}$ Essa dualidade estrutural do abuso de direito repercute na teoria da responsabilidade civil: o exercício regular de um direito constitui excludente de responsabilidade civil; o exercício irregular ou abusivo enseja o dever de reparação do dano. ${ }^{25}$

Em suma, ao contrário do entendimento esposado pelo Superior Tribunal de Justiça, o jornalista se prevaleceu de sua condição para atacar e difamar a advogada, ofendendo-a em sua dignidade pessoal e profissional. Com isso, praticou ato ilícito que enseja o dever de reparar os danos causados.

20 LIMA, Alvino. Culpa e risco. 2. ed. atual. por Ovídio Rocha Barros Sandoval. São Paulo: RT, 1998, p. 205.

21 TARTUCE, Flávio. Direito civil: v. 2 - direito das obrigações e responsabilidade civil. 13. ed. Rio de Janeiro: Forense, 2018, p. 334.

22 Aguiar Dias menciona que, ao lado do dever geral de não prejudicar outrem, há um direito de prejudicar. Mas, para que se possa exercê-lo, é preciso estar autorizado em relação ao sujeito passivo da ação prejudicial (DIAS, José de Aguiar. Da responsabilidade civil. 2. ed. Rio de Janeiro: Forense, 1950. v. II, p. 97-98).

23 Sobre a ilicitude intrínseca do dano, confira-se: SANTOS, Romualdo Baptista dos. Responsabilidade civil por dano enorme. Curitiba-Porto: Juruá/Porto Editora, 2018, p. 124-126 e 150-152.

24 Essa é a posição esposada por Flávio Tartuce, com lastro na lição de Limongi França (TARTUCE, Flávio. Direito civil, cit., v. 2, p. 334; TARTUCE, Flávio. A construção do abuso de direito nos dez anos do Código Civil brasileiro de 2002. Revista Jurídica Luso-Brasileira, ano 1, n. 6, p. 447-472, [2015]. Disponível em <https://www.cidp.pt/publicacoes/revistas/ rjlb/2015/6/2015_06_0447_0472.pdf>. Acesso em: 14 jul. 2018.

25 RODRIGUES, Silvio. Direito civil, cit., v. 4, p. 50; PEREIRA, Caio Mário da Silva. Responsabilidade civil. Rio de Janeiro: Forense, 1989, p. 315-316. 


\section{CONCLUSÃo}

Do que foi desenvolvido nos itens acima, a liberdade de expressão é essencial para que o ser humano se constitua como pessoa, assim como é condição de possibilidade para a instalação e conservação do Estado Democrático de Direito. A liberdade de expressão é gênero que contém inúmeras espécies, consoante as múltiplas formas de manifestação da personalidade. Entre as várias formas de manifestação da personalidade, distinguem-se a liberdade de imprensa e as prerrogativas dos profissionais do direito, por sua relevância para o pleno exercício e constante aperfeiçoamento do regime democrático.

No caso Zandonade, a procuradora da Fazenda Nacional moveu ação de reparação de dano moral em razão de reportagem veiculada pelo jornal Folha de $S$. Paulo, em que o jornalista tece críticas ásperas à sua atuação profissional. Contrariando os julgamentos proferidos nas duas instâncias anteriores, o Superior Tribunal de Justiça acolheu o Recurso Especial do jornalista e da empresa jornalística, aos argumentos de que os servidores públicos estão sujeitos a avaliação permanente pela sociedade e pela mídia e de que as críticas lançadas pelo jornalista não atingiram a honra nem a imagem da autora.

Verifica-se que o julgador mencionou a técnica da ponderação de Robert Alexy, mas não chegou a aplicar sua metodologia, limitando-se a realizar apreciação subjetiva, em que minimiza a agressividade das expressôes lançadas pelo jornalista, às quais a advogada estaria sujeita em razão de sua condição de servidora pública.

A rigor, a questão deveria ser enfrentada pelo prisma do abuso de direito, em que o agente pratica ato ilícito ao se exceder no exercício de seu direito. O jornalista desfruta do direito garantido constitucionalmente de noticiar, opinar e criticar os fatos, mas ao fazê-lo não pode se exceder e atingir os direitos da personalidade das outras pessoas, pena de cometer abuso de direito.

No caso, melhor andaria o Superior Tribunal de Justiça se mantivesse a condenação do jornalista e da empresa jornalística, nos termos da sentença e do acórdão recorridos. Isso porque as expressões injuriosas lançadas na reportagem ultrapassam o limite do exercício regular de um direito e configuram abuso de direito, que é ato ilícito e enseja dever de reparação.

\section{REFERÊNCIAS}

ALEXY, Robert. Teoria dos direitos fundamentais. Tradução de Virgílio Afonso da Silva. São Paulo: Malheiros, 2008.

BARROSO, Luís Roberto. Neoconstitucionalismo e constitucionalização do direito (o triunfo tardio do direito constitucional no Brasil). Revista de Direito Administrativo, Rio 
de Janeiro: FGV, p. 1-42, abr.-jun. 2005. Disponível em: <http://bibliotecadigital.fgv. br/ ojs/index.php/rda/article/view/43618/44695>. Acesso em: 29 maio 2018.

BARROSO, Luís Roberto. Colisão entre liberdade de expressão e direitos da personalidade. Critérios de ponderação. Interpretação constitucionalmente adequada do Código Civil e da Lei de Imprensa. Migalhas. Disponível em: <http://www.migalhas.com.br/arquivo_artigo/art_03-10-01.htm>. Acesso em: 14 jul. 2018.

BITTAR, Carlos Alberto. Os direitos da personalidade. 7. ed. atual. por Eduardo Carlos Bianca Bittar. Rio de Janeiro: Forense Universitária, 2004.

CANOTILHO, José Joaquim Gomes. Estudos sobre direitos fundamentais. 1. ed. 3. tir. São Paulo-Coimbra: RT/Coimbra Ed., 2008.

CAVAlIERI FILHO, Sergio. Programa de responsabilidade civil. 6. ed. São Paulo: Malheiros, 2005.

CHAUI, Marilena. Heidegger: vida e obra. São Paulo: Nova Cultural, 1999 (Coleção Os Pensadores).

DIAS, José de Aguiar. Da responsabilidade civil. 2. ed. Rio de Janeiro: Forense, 1950. v. II.

FACHIN, Luiz Edson. Teoria crítica do direito civil. 2. ed. Rio de Janeiro: Renovar, 2003.

FACHIN, Luiz Edson. Estatuto jurídico do patrimônio mínimo. 2. ed. Rio de Janeiro: Renovar, 2006.

FRANÇA, Rubens Limongi. Manual de direito civil. 4. ed. São Paulo: RT, 1980. v. 1. GONÇALVES, Carlos Roberto. Responsabilidade civil. 9. ed. São Paulo: Saraiva, 2005.

KAUFMANN, Arthur. La filosofía del derecho en la posmodernidad. 2. ed. Santa Fé de Bogotá: Temis, 1998.

LIMA, Alvino. Culpa e risco. 2. ed. atual. por Ovídio Rocha Barros Sandoval. São Paulo: RT, 1998.

MATURANA, Humberto. Emoções e linguagem na educação e na política. Tradução de José Fernando Campos Fortes. 4. reimp. Belo Horizonte: Editora da UFMG, 2005.

PEREIRA, Caio Mário da Silva. Responsabilidade civil. Rio de Janeiro: Forense, 1989.

RODRIGUES, Silvio. Direito civil: v. 4 - responsabilidade civil. 4. ed. São Paulo: Saraiva, 1979.

SANTOS, Romualdo Baptista dos. A tutela juridica da afetividade. Curitiba: Juruá, 2011. SANTOS, Romualdo Baptista dos. Responsabilidade civil por dano enorme. Curitiba-Porto: Juruá/Porto Editora, 2018.

SANTOS, Romualdo Baptista dos. Pela atualização da súmula 54 do STJ. Revista de Estudos Jurídicos e Sociais, 6. ed., n. 6, p. 57-77, out. 2017.

SOUZA, Rabindranath Capelo de. O direito geral de personalidade. Lisboa-Coimbra: Coimbra Ed., 2011. 
•• Direito Civil: Estudos | Coletânea do XV Encontro dos Grupos de Pesquisa - IBDCivil

TARTUCE, Flávio. Direito civil: v. 2 - direito das obrigaçōes e responsabilidade civil. 13. ed. Rio de Janeiro: Forense, 2018.

TARTUCE, Flávio. A construção do abuso de direito nos dez anos do Código Civil brasileiro de 2002. Revista Jurídica Luso-Brasileira, ano 1, n. 6, p. 447-472, [2015]. Disponível em: <https://www.cidp.pt/publicacoes/revistas/rjlb/2015/6/2015_06_0447_0472.pdf>. Acesso em: 14 jul. 2018. 